Historia Slavorum Occidentis

2021, nr 4 (31)

ISSN 2084-1213

DOI: $10.15804 /$ hso210408

Pawee Glugla (Tarnów)

ORCID: 0000-0002-5940-9105

\title{
Problematyka migracyjna XX wieku a troska Kościoła katolickiego o wychodźców sezonowych na przykładzie diecezji tarnowskiej w latach 1910-1913
}

Keywords: seasonal emigration, Catholic Church, Tarnów diocese, $20^{\text {th }} \mathrm{c}$.

Słowa kluczowe: wychodźstwo sezonowe, Kościół katolicki, diecezja tarnowska, XX w.

Abstract: The late $19^{\text {th }}$ century witnessed increased migration from the Polish territory, including the then Galicia, Eastern Europe. The Catholic church played a special role in caring for young seasonal immigrants. Among the numerous forms and preventive measures was organising and conducting spiritual retreats for seasonal immigrants, including the Tarnów diocese.

Tytułem wprowadzenia, należy podkreślić, że z końcem XIX i początkiem XX w. występowała nienotowana wcześniej na tak dużą skalę migracja Polaków do bogatych krajów Europy (Niemcy, kraje skandynawskie, Francja ${ }^{1}$, Wielka Brytania, kraje południowoeuropejskie) - zwana kontynentalną (europejską) oraz zamorska - do Ameryki Północnej (USA, Kanada)² i Ameryki Południowej (głównie do Brazylii) ${ }^{3}$.

1 I.W. Kosmowska, Nasze wychodźstwo do Francji, Ziemia. Dwutygodnik krajoznawczy ilustrowany 13 (1928), s. 202-205.

2 Por. M. Borys, Z dziejów galicyjskiego wychodźstwa zarobkowego do Stanów Zjednoczonych, Szkice Tarnowskie 1 (2010), s. 89-102.

3 Polacy emigrowali oprócz Westfalii i Francji również do Danii, jako pracownicy rolni. Por. Polacy na obczyźnie, IV: Polacy w Danii, Goniec Śląski, 4 X 1928, nr 230, s. 5. 
Przyczyny tychże migracji związane były z sytuacją polityczno-gospodarczo-ekonomiczną panującą na ówczesnych ziemiach polskich będących pod trzema zaborami, a zwłaszcza w ubogiej Galicji. Emigranci zarobkowi rekrutowali się również z Królestwa Polskiego 4 . Polacy migrowali za chlebem czasowo (w celach zarobkowych), a także przesiedlali się całymi rodzinami na stałe (osadnictwo stałe) ${ }^{5}$. Z ówczesnej Galicji najczęściej emigrowano za pracą, sezonowo do krajów europejskich.

Dotychczas wieloaspektowe zagadnienia migracji zostały już obszernie opisane w literaturze przedmiotu. Główne kierunki polskiej myśli naukowej związanej z problematyką emigracyjną reprezentowali przed pierwszą wojną światową i w Polsce międzywojennej m.in.: Aleksander Kościesza ${ }^{6}$, Florian Znaniecki, Leopold Caro, Ludwik Krzywicki. Ze współczesnych natomiast przykładowo można wymienić Adama Walaszka ${ }^{7}$, Adama Pilcha ${ }^{8}$, Jerzego Mazurka ${ }^{9}$, Dorotę Praszałowicz ${ }^{10}$, Adama Koseskiego ${ }^{11}$. Tematyka ta jest nadal przedmiotem badań i analiz historyków, socjologów, etnografów, ekonomistów, teologów, psychologów i badaczy innych specjalności.

4 Nad tematem tym pochyliła się m.in. Janina Kulikowska. Zob. tejże, Emigracja i duszpasterstwo wychodźców z Królestwa Polskiego do roku 1914 ( $w$ świetle urzędowych publikacji kościelnych), Nasza Przeszłość 65 (1986), s. 91-143.

5 A. Pilch, Emigracja z ziem zaboru austriackiego (od połowy XIX w. do 1918 r.), [w:] Emigracja $z$ ziem polskich $w$ czasach nowożytnych $i$ najnowszych $w X V I I I-X X w$., red. A. Pilch, Warszawa 1984, s. 252-325; Szerzej: M. Kozaczka, Emigracja zarobkowa z powiatu tarnowskiego do r. 1939, Przegląd Polonijny 3 (1990), z. 16, s. 59-76.

6 Warto zwrócić uwagę na niewielką publikację A. Kościeszy, Robotnik rolny a wychodźtwo[!], Warszawa 1913. Podał w niej kwintesencję wychodźstwa, a także wiele bieżących informacji, w tym o połączeniach transportowych z cennikami biletów.

7 A. Walaszek, Migracje Europejczyków 1650-1914, Kraków 2007; tenże, Reemigracja ze Stanów Zjednoczonych do Polski po I wojnie światowej, 1919-1924, Kraków 1983; tenże, Polscy robotnicy, praca i zwiazki zawodowe w Stanach Zjednoczonych Ameryki, 1880-1922, Wrocław 1988; tenże, Światy imigrantów. Tworzenie polonijnego Cleveland, Ohio 1880-1930, Kraków 1994.

8 Emigracja z ziem polskich $w$ czasach nowożytnych i najnowszych $w$ XVIII-XX w., red. A. Pilch, Warszawa 1984.

9 J. Mazurek, Kraj a emigracja. Ruch ludowy wobec wychodźstwa chłopskiego do krajów Ameryki Łacińskiej (do 1939 roku), Warszawa 2006.

10 Mechanizmy zamorskich migracji łańcuchowych $w$ XIX wieku: Polacy, Niemcy, Żydzi, Rusini. Zarys problemu, red. D. Praszałowicz, K. Makowski, A.A. Zięba, Kraków 2004.

11 A. Koseski, Procesy migracji i społeczności polonijne. Problematyka metodologiczno-historiograficzna, Pułtusk 2003. 
Nie zachowały się akta Urzędu Emigracyjnego i większość akt Ministerstwa Opieki Społecznej, które uległy zniszczeniu podczas drugiej wojny światowej. Natomiast w Centralnym Archiwum Historycznym Ukrainy we Lwowie znajduje się m.in. duży zespół akt liczący 3367 j.a. Ekspozytury Urzędu Emigracyjnego we Lwowie, a także mniejsze zespoły tejże proweniencji ${ }^{12}$. Cenne zespoły zasobów akt tematyki migracyjnej znajdują się w archiwach kościelnych (zwłaszcza diecezjalnych), w tym przypadku w Archiwum Diecezji Tarnowskiej im. abpa J. Ablewicza.

Szczególnym rodzajem migracji zarówno w czasach zaborów, jak i później, były zarobkowe migracje sezonowe. Na potrzeby niniejszego tekstu został dokonany przegląd problematyki migracyjnej pod kątem organizacji życia duchowego i praktyk religijnych migrantów sezonowych diecezji tarnowskiej. Diecezja ta stanowiła galicyjskie „zagłębie emigracyjne”, dostarczając największej liczby emigrantów. $\mathrm{Z}$ uwagi na masowość owej migracji, zwłaszcza na początku XX w., jawi się wiele pytań, w tym pod kątem organizacji i życia moralno-religijnego migrantów: czy i jak duchowieństwo, w tym przypadku diecezji tarnowskiej, położonej w Galicji (zabór austrowęgierski) dbało o religijność i praktyki duchowe młodych migrantów, którzy na stałe mieszkali w parafiach tejże diecezji, a czasowo (sezonowo) migrowali do innych krajów, oraz w jaki sposób je organizowało. Jednym z ważnych zadań, które zlecił podległemu sobie duchowieństwu biskup tarnowski Leon Wałęga (1859-1933), było organizowanie i prowadzenie rekolekcji dla sezonowych wychodźców. Spośród wielu zgromadzeń w diecezji wybór biskupi padł na Zgromadzenie Misji św. Wincentego a Paulo i urządzenie rekolekcji w Tarnowie w misjonarskiej parafii pw. Świętej Rodziny. Kto je prowadził, jaką poruszano tematykę oraz jaka była frekwencja? Dotychczasowy stan badań w tym zakresie wydaje się niewystarczający, a niektóre zagadnienia, w tym istotne - jak np. szczególowy zakres i tematyka nauk rekolekcyjnych - pomijane. Ze współczesnych badaczy tegoż problemu można wymienić - pochodzącego z diecezji tarnowskiej - ks. Stanisława Piecha ${ }^{13}$, a z diecezji krakowskiej ks. Jerzego Dyktusa ${ }^{14}$.

Problematykę migracyjną w diecezji tarnowskiej dostrzegał już w XIX w. ówczesny jej biskup Józef Alojzy Pukalski (1798-1885), wydając 24 III 1880 r. w tym

\footnotetext{
12 Zob. J. Mazurek, Kraj a emigracja, s. 13.

13 Zob. S. Piech, Emigracja z diecezji tarnowskiej $w$ świetle ankiet konsystorza $z$ lat 1907 i 1910, Nasza Przeszłość 65 (1986), s. 145-197.

14 J. Dyktus, Emigracja i opieka duszpasterska nad emigrantami $w$ diecezji krakowskiej $w$ świetle ankiet konsystorza z 1907 i 1913 roku, Studia Polonijne 2 (1977), s. 113-180.
} 
zakresie list pasterski ${ }^{15}$. Impulsem do jego opublikowania było pismo rządu austriackiego, który wzywał biskupa i duchowieństwo do przeciwdziałania szerzącej się fali emigracji ${ }^{16}$. Biskup Pukalski w swoim piśmie z 15 VI 1880 r. ostrzegał diecezjan przed lekkomyślnym udawaniem się do Ameryki ${ }^{17}$. Przeciw emigracji oficjalnie występowano również w lokalnej, świeckiej prasie końcem XIX w ${ }^{18}$. Często bowiem zdarzały się przypadki nieuczciwości zarówno ze strony pośredników werbujących tanią siłę roboczą, jak i miejscowych pracodawców, a zwłaszcza pośredników ${ }^{19}$. Nadto w lokalnej prasie sporo było rozmaitych reklam ${ }^{20}$. Również co pewien czas pojawiły się doniesienia w sprawie wychodźstwa, zwłaszcza sezonowego, w których poruszano $\mathrm{m}$.in. sprawy paszportowe ${ }^{21}$, ankiety emigracyjnej ${ }^{22} \mathrm{i}$ inne. Rozporządzeniem z 29 V 1889 r. (1. 12308), c.k. Starostwo tarnowskie rozesłało do wszystkich naczelników gmin okólnik,

mocą którego na wójtów nałożono ścisły obowiązek, by wszystkich chcących emigrować do Ameryki, wszelkimi powstrzymywali środkami, a o każdym, kto opuści gminę w zamiarze emigracji niezwłocznie [należało] donieść c.k. Starostwu. Rozporządzenie to wydane zostało na podstawie wiarygodnych wiadomości o opłakanych stosunkach roboczych i zarobkowych w Ameryce, gdzie wyżywienie ma być o wiele nawet trudniejsze niż w naszym kraju. Wobec tego

15 List biskupa tarnowskiego J.A. Pukalskiego [z 24 III 1880 r.], Currenda. Pismo urzędowe diecezji tarnowskiej [Currenda] 30 (1880), nr 9, s. 65-67.

16 Tamże, s. 85.

17 Zob. J.A. Pukalski, Ostrzeżenie włościan polskich by lekkomyślnie kraju rodzinnego nie opuszczali, aby w Ameryce szukać rzekomej poprawy losu swego, tamże, 30 (1880), nr 14, s. $106-112$.

18 Zob. Skutki wychodźstwa do Ameryki, Krakus. Pismo poświęcone sprawom politycznym i społecznym, 4 VI 1892, nr 23, s. 8.

19 O tzw. „agentach werbunkowych” szerzej: G.M. Kowalski, Przestępstwa emigracyjne w Galicji 1897-1918. Z badań nad dziejami polskiego wychodźstwa, Kraków 2003.

20 Przykładem mogą być inseraty Zofii Biesiadeckiej, właścicielki biura podróży w Oświęcimiu, która oferowała bilety okrętowe I, II i III klasy do Ameryki i Kanady z dopiskiem „Kto się chce uchronić od wyzysku i zwodów, niech żąda pouczeń wprost bo nie mam żadnych agentów i naganiaczy”. Zob. Pogoń, 18 VII 1909, nr 29, s. 6; tamże, 18 I 1914, nr 3, s. 3; Por. Inserat firmy Austro-Americana, Tygodnik Mieszczański, 5 X 1913, nr 40, s. 9.

21 Kronika miejscowa $i$ zamiejscowa. W sprawie paszportów dla wychodźców, Pogoń, 11 II 1912, nr 6, s. 12.

22 Ankieta emigracyjna, tamże, 24 III 1912, nr 12, s. 1. 
nie tylko naczelnicy gmin, ale wszyscy dobrze myślący ludzie powinni się starać odwodzić lud od zgubnej dla niego i dla kraju emigracji²3.

Przestrzegano migrantów, szczególnie ze wsi, o praktykowanym wyzysku siły roboczej z Galicji, zwłaszcza w Niemczech. Apelowano o organizowanie większych grup mogących skuteczniej bronić się przed nieuczciwymi pracodawcami ${ }^{24}$. Trzeba podkreślić, że spora część migrantów była analfabetami, stąd też łatwo było zarówno nieuczciwym pośrednikom, jak i pracodawcom nimi manipulować, a nierzadko i oszukiwać. W 1891 r. w Wiedniu powstało „Towarzystwo św. Rafała” do opieki nad uchodźcami, w tym do Ameryki Północnej ${ }^{25}$. Natomiast w 1908 r. w Krakowie powołano do istnienia Polskie Towarzystwo Emigracyjne (PTE) ${ }^{26}$, które było stowarzyszeniem zarobkowo-gospodarczym, utworzonym na podstawie ustawy z $9 \mathrm{IV}$ $1873 \mathrm{r}^{27} \mathrm{Z}$ chwilą wybuchu pierwszej wojny światowej PTE zawiesiło swoją działalność, by nigdy więcej się nie reaktywować. Należy wspomnieć, że jednym z celów powstania i działalności owych towarzystw/stowarzyszeń była troska o losy migrantów, w tym również pochodzących z diecezji tarnowskiej, a zwłaszcza chronienie wychodźców przed wyzyskiem i stratami w drodze i podczas pobytu na obczyźnie, oraz ułatwianie im powrotu do kraju ojczystego. Nie zawsze udawało się uchronić latwowiernych migrantów przed nieuczciwymi agentami emigracyjnymi ${ }^{28}$. Młodzi nie tylko udawali się w celach zarobkowych do innych krajów, bowiem emigracyjną

\footnotetext{
23 Por. Kronika miejscowa i zamiejscowa. Przeciw emigracji, tamże, 16 VI 1889, nr 24, s. 5.

24 Zob. Sidziniarz, Organizujmy się!, Związek Chłopski, 11 XII 1904, nr 32, s. 1-2.

25 Statut przewidywał, że: „Austryackie Stowarzyszenie św. Rafaela bierze sobie za zadanie chronić katolickich wychodźców przynależnych do kraju w Radzie państwa reprezentowanych przed grożącemi im niebezpieczeństwami a w szczególności: a) Pod względem ich religii i obyczajności; b) majątku; a to od chwili powzięcia zamiaru emigrowania aż do chwili otrzymania pracy u celu wędrówki. Stowarzyszenie nie ma wcale zamiaru popierać wychodźstwa; ale tylko tych, którzy w zamiarze wychodźstwa niewzruszenie trwają chronić przed wyzyskiem według możności. Do osiągnienia tego celu mają służyć następujące środki: 1. Rozpowszechnianie pism pouczających wychodźców, 2. Ustanowienie w najbardziej frekwentowanych portach mężów zaufania, którzyby mówili językiem monarchii, 3. Polecenie wychodźców osobom zaufania godnym w główniejszych punktach ruty podróżnej”. Zob. G., Austryackie stowarzyszenie św. Rafała, Gwiazda katolicka, 15 X 1890, nr 20, s. 347-349.

26 Pełna jego nazwa brzmiała: „Polskie Towarzystwo Emigracyjne” stowarzyszenie zarejestrowane $z$ ograniczona poręka z siedziba w Krakowie. Zob. G.M. Kowalski, Przestępstwa emigracyjne, s. 80-86.

27

28

Tamże, s. 95-97.

Zob. Ofiary agentów emigracyjnych, Pogoń, 29 III 1914, nr 13, s. 4.
} 
ucieczką salwowali się z miejsca zamieszkania niektórzy poborowi, chcąc uniknąć spełnienia ciążącego na nich obowiązku wojskowego ${ }^{29}$.

$\mathrm{W}$ tarnowskiej prasie publikowane były teksty zawierające w swojej treści smutek z powodu ubywających rąk do pracy, wskazywano winnymi nie tylko samych migrantów, ale ówczesne władze świeckie. Ubolewano nad tym, że najlepsi opuszczają kraj rodzinny, aby na obczyźnie szukać kawałka chleba, a następnie powracają „ "w cudacznym ubiorze i z połamanym językiem, bo macierzysta mowa już im obrzydła" ${ }^{30}$. Winą za taki stan rzeczy obarczano nie tyle samych migrantów, ale polityków i rządzących, którzy nie wykazywali chęci do zaradzenia problemom, gdyż górę brały czynniki partykularne. Nadto przedstawiano obszerną aktualnie panującą sytuację rynku pracy w danym kraju, np. w Stanach Zjednoczonych, posiłkując się niesprzyjającym dla Europejczyków klimatem oraz oszukiwaniem nieświadomych migrantów płatnością za pracę wycofanymi z obiegu bezwartościowymi banknotami jak też coraz lichszą płacą, zwłaszcza w Luizjanie i południowych stanach, ze względu na panującą tam wówczas recesję $e^{31}$.

Należy wspomnieć o publikacjach, zwłaszcza poradnikach dla wychodźców udających się okresowo bądź na stałe do różnych krajów, zarówno europejskich, jak i na innych kontynentach. Dedykowano je migrantom udającym się do Francji ${ }^{32}$, Brazylii ${ }^{33}$, Ameryki $^{34} \mathrm{i}$ innych krajów. Wydawcami owych poradników były takie organizacje, jak: Polskie Towarzystwo Emigracyjne, Urząd Emigracyjny (w serii: Mała biblioteka emigranta polskiego), a także inne instytucje. Nadzór państwowy nad wychodźstwem z Polski pełnił Urząd Emigracyjny. Pod jego kontrolą odbywało się werbowanie robotników do pracy za granicą. Nadto urząd ów roztaczał opiekę nad emigrantami w czasie podróży, pilnował przestrzegania stosowania praw i konwencji emigracyjnych na miejscu pracy oraz współdziałał z polskim Ministerstwem Skarbu w organizacji przesyłania oszczędności do kraju ${ }^{35}$.

\footnotetext{
29 Zob. O wolność emigracji, tamże, $17 \mathrm{~V}$ 1914, nr 20, s. 2.

30 Korespondencye. W.Z., Z Dąbrowskiego w lipcu, tamże, 15 VII 1900, nr 56, s. 2.

31 Przestrogi dla wychodźców, tamże, 1 III 1908, nr 9, s. 3.

32 Poradnik dla wychodźcy. O czem emigrant zarobkowy we Francji wiedzieć powinien, oprac. S. Klimowicz, Paryż 1923.

33 Wskazówki dla wychodźców do Brazylii, Warszawa 1929.

34 Wskazówki dla wychodźców udających się do Ameryki oraz rozmówki polsko-angielskie, ułożył J. Okołowicz, Kraków 1911.

35 Poradnik dla wychodźcy, s. 6.
} 
O sprawy i zagadnienia migrantów troszczył się również Kościół katolicki. Dbał o stan moralno-duchowy migrujących, zwłaszcza młodych. W Poznaniu z inicjatywy prymasa kard. Augusta Hlonda ${ }^{36}$ powstało Towarzystwo Chrystusowców dla Polonii Zagranicznej oraz Polska Misja Katolicka (PMK) utworzona jako stałe katolickie duszpasterstwo Polonii działające w wielu krajach, podlegające Konferencji Episkopatu Polski (KEP). Przykładowo we Francji sprawowanie opieki religijnej opierało się na zasadzie umieszczania w większych skupiskach polskich stałych kapelanów, objeżdżających najbliższe sąsiednie okręgi zamieszkałe przez Polaków. Prapoczątki PMK sięgają emigracji politycznej po upadku powstania listopadowego $1831 \mathrm{r}$. głównie do Wielkiej Brytanii i Francji ${ }^{37}$.

Dla przyjeżdżających na święta w rodzinne strony migrantów urządzano rekolekcje z naukami stanowymi. Biskup tarnowski Leon Wałęga dostrzegał zarówno pozytywne, jak i negatywne moralno-etyczne i materialne skutki migracji zarobkowej diecezjan. Zwracał uwagę na wszelkie szkody moralne, liczne niebezpieczeństwa, na które narażeni byli wychodźcy w obcych krajach. Cytował bardzo smutne wyjątki z pism niemieckich, które rzucały negatywne światło na zachowanie się wielu wychodźców za granicą ${ }^{38}$. Dlatego też polecał duchowieństwu parafialnemu, „by dołożyło wszelkich starań dla obrony swych owieczek na wychodźstwie przed grożącym im zepsuciem i utratą wiary” ${ }^{39}$. Apelował do proboszczów, że „należy ostrzegać, prosić i błagać wychodźców, by pamiętali na przykazania Boże, trzeba karcić błędy i złe nałogi, a nawet piętnować je w pismach ludowych i na kazalnicy, lecz bez wymieniania nazwisk" ${ }^{40}$. Polacy w wielu krajach mieli opinię pracowitych, ale i lekkomyślnie marnujących ciężko zarobione pieniądze ${ }^{41}$. Biskup zauważył i bolał nad tym, że najbardziej na obczyźnie dokuczał Polakom głód polskiego kapłana ${ }^{42}$. Wraz z czasową rozłąką małżonków nierzadko pojawiały się zdrady, rozwody, a nawet bigamie, poza

36 Prymasowi zależało na dobru wychodźców i wychodźstwie. Zob. Odezwa Ks. Kardynała Prymasa Polski o emigracji, Głos Pracy, 1 IV 1930, nr 7, s. 3-4.

37 Szerzej: B. Kołodziej, Opieka duszpasterska nad wychodźcami polskimi do roku 1939, Poznań 2003.

38 Okresowo pisała o tym również tarnowska prasa. Por. Kronika miejscowa i zamiejscowa. Rozwiązłość na Saksach, Pogoń, 29 VIII 1909, nr 35, s. 5.

39 Por. J. Badeni, Robotnicy polscy w Saksonii, Przegląd Powszechny. Miesięcznik poświęcony sprawom religijnym, kulturalnym i społecznym 7 (1890), t. 28, s. 322.

40 Tamże.

41 Tamże.

42 Zagadnienie to opisał ks. S. Piech w tekście Opieka. 
tym pijaństwo, rozrzutność, swawola, prostytucja. Jednakże wielu żyło uczciwie i nie marnowało ciężko zarobionych na obczyźnie pieniędzy ${ }^{43}$. Zebrawszy wszystkie pozytywne i negatywne skutki migracji, bp L. Wałęga 20 I 1906 r. wydał obszerny list o uchodźstwie, zatytułowany „Archanioł Rafał” ${ }^{4}$. Zawarł w nim szczegółowo rady i zalecenia oraz obowiązki i przestrogi, jakie powinny przyświecać wyjeżdżającym i powracającym migrantom. List ten był wydrukowany w dużym nakładzie $\mathrm{w}$ formie broszurowej, do rozpowszechnienia go pomiędzy wychodźcami. Celem umoralnienia wychodźców wracających do domów, zgodnie z intencją bpa Wałęgi, a także księży dziekanów wielokrotnie obradujących w tych kwestiach na kongregacjach dekanalnych, były między innymi ${ }^{45}$ organizowane specjalnie dla migrantów rekolekcje w kościele księży Misjonarzy w Tarnowie ${ }^{46}$. Rekolektantami byli wyłącznie księża Misjonarze aktualnie pracujący w tarnowskiej parafii. Jedną z nauk wygła-

43 Problemy migracyjne Polaków na obczyźnie były poruszane przez księży Misjonarzy, którzy im duszpasterzowali. Pisano, że „na ogół rodacy nasi są bardzo oszczędni, zwłaszcza ci, którzy muszą utrzymywać swoje rodziny w Polsce. Zdarzają się i takie wypadki, że żyją o chlebie i wodzie lub gotowanych na wodzie ziemniakach, byle tylko grosz zaoszczędzić”. Zob. P. Kurtyka CM, $Z$ pracy duszpasterskiej wśród robotników polskich we Francji, Roczniki Obydwóch Zgromadzeń św. Wincentego a Paulo 25 (1923), nr 1, s. 22.

44 Pierwotnie wydrukowany w „Currendzie” nr 1-3 z 1906 r., a następnie w formie broszury. Zawierał rozdziały: „Jechać, czy nie jechać?”, „Wybieranie się w drogę”, „Pobyt na obczyźnie”, „Powrót do domu”, „Uwagi dodatkowe”. Otrzymywali go wychodźcy przed wyruszeniem w drogę na obczyznę.

45 Pośród innych zaleceń podawano, aby migranci wybierali się na roboty w jedno miejsce w większej liczbie, zapisywali się na obczyźnie do polskich i katolickich stowarzyszeń, prenumerowali dobre czasopisma, nie wstydzili się przed protestantami i innymi swojej wiary katolickiej i narodowości. Nadto duszpasterzy zobowiązano do wyjaśniania różnic pomiędzy wiarą katolicką, a protestantyzmem i zachęcania wychodźców chcących skorzystać z posługi duchowej kapłanów, aby przysyłali swoje adresy (zwłaszcza większych grup) do Konsystorza Biskupiego albo do swojego proboszcza. Zob. Sprawozdanie z pracy misyjnej w Król. Saskiem w r. 1912, Currenda 53 (1913), nr 4, s. 30-32.

46 Na konferencji dziekanów 9 XI 1911 r. ustalono wytyczne dla duszpasterzy. Mieli oni prowadzić statystyczne wykazy emigrantów; pouczać parafian, by wyjeżdżali tylko z kontraktami zawartymi nie z byle agentem, ale przez biuro pośrednictwa pracy; czuwać, by nieletnie dzieci nie wyjeżdżały do pracy; urządzać dla wyjeżdżających małe rekolekcje; korespondować z nimi i przesyłać im zaprenumerowane dla nich pisma; w czasie sezonu kapłani winni więcej modlić się za swoich emigrantów i pobudzać innych do modlitwy; po powrocie emigrantów do domu należało im urządzić uroczyste powitanie z odpowiednią nauką; zachęcać każdego do spowiedzi, a zwłaszcza do wzięcia udziału w rekolekcjach u XX. Misjonarzy w Tarnowie; duszpasterz miał za zadanie przeprowadzić bezpośrednią rozmowę z każdym wychodźcą. Zob. O opiece nad emigrantami (referat X. prałata dr Jana Bernackiego), tamże, 62 (1912), nr 2, s. 35-36. 
szał bp Wałęga. Zaplanowano dwie serie rekolekcji: dla dziewcząt (od poniedziałku 3. niedzieli adwentu 1910 r.) i dla młodzieńców (od poniedziałku po 4. niedzieli adwentu t.r.). Obowiązkiem duszpasterzy w diecezji było zachęcić powracających „obieżysasów” do wzięcia w nich udziału ${ }^{47}$. Zgłoszenia chętnych należało podawać w tarnowskiej kancelarii konsystorskiej do 6 grudnia ${ }^{48}$. Przyjezdnym rekolektantom $\mathrm{z}$ dalszych terenów diecezji księża Misjonarze zapewniali nocleg i wikt przez trzy dni za symboliczną odpłatnością 30-40 halerzy dziennie ${ }^{49}$. Były to rekolekcje zamknięte $^{50}$. Gdyby liczba chętnych była duża ${ }^{51}$, Misjonarze byli gotowi urządzić po Nowym 1911 r. kolejne serie takich rekolekcji. Pierwsze rekolekcje na prośbę bpa L. Wałęgi dla powracających z Prus na święta Bożego Narodzenia młodych 1270 migrantów przeprowadzili księża Misjonarze w dniach od 12 XII 1910 r. (dla 752 dziewcząt) i od 19 grudnia (dla 518 młodzieńców) ${ }^{52}$. Wypadły one nadzwyczaj pozytywnie ${ }^{53}$, stąd też wdzięczny księżom Misjonarzom bp Wałęga usilnie zachęcał do przeprowadzania kolejnych serii rekolekcji. Wydał 18 XI 1911 r. w tej sprawie odezwę do duchowieństwa i diecezjan ${ }^{54}$. O odbytych rekolekcjach w kościele księży Misjonarzy

47 Zob. J. Adamczyk, Działalność duszpasterska na rzecz wychodźców galicyjskich w diecezji tarnowskiej, Tarnów 1978, mps, Archiwum Instytutu Teologicznego w Tarnowie, sygn. 01341 MGR.

48 Zob. L. Wałęga, WW Duchowieństwu Diecezyi pozdrowienie i błogosławieństwo, Currenda 60 (1910), nr 15, s. 153-160.

49 Dotacji m.in. udzieliło Towarzystwo św. Józefa w Tarnowie. W sprawozdaniu tegoż Towarzystwa za 1914 r. podano, że na rekolekcje dla wychodźców sezonowych udzielono księżom Misjonarzom dotacji w kwocie 300 koron. Zob. Sprawozdanie kasowe, tamże, 64 (1914), nr 13, s. 67.

50 Rekolekcje, w tym zamknięte, zalecal papież Pius XI w encyklice Mens nostra [z 20 XII 1929

r.]. Zob. „Acta Apostolicae Sedis” 1929, t. 21, nr 16, s. 689-706.

51 W jednej serii nie mogło być więcej niż 500 uczestników ze względu na wielkość pomieszczeń, liczbę miejsc oraz obsługę. Zob. L. Wałęga, WW. Duchowieństwu, s. 165.

52 AKMT, Kronika parafii, t. 1, s. 9.

53 Świadczyły o tym przysyłane do konsystorza biskupiego pisma oraz ankiety z poszczególnych parafii, z których rekrutowali się migranci-rekolektanci. Miało to również przełożenie na życie religijne owych migrantów, o czym niejednokrotnie sami mówili. Zob. AKMT, Kronika parafii, t. 1, s. 9-10; Rekolekcye dla wychodźców, Currenda 61 (1911), nr 10, s. 97-98.

54 Jej treść in extenso: „Z nadchodzącą zimą wracają znowu do nas te tłumy wychodźców, które $\mathrm{z}$ wiosną wyruszyły za granicę dla zarobku, a wracają przeważnie w stanie godnym opłakania. Dusze ich potrzebują kąpieli i to przeważnie gruntownej, aby parafia i proboszczowie przyznać się do nich mogli. Wiem o tem, że wielu z X.X. Proboszczów stara się o to aby powracających wychodźców jak najprędzej pojednać z P. Bogiem przez spowiedź, a przez nauki, a nawet rekolekcye tu i ówdzie urządzane usunąć z ich wszystkie te niedobre naleciałości, jakie z zagranicy 
w Tarnowie świadczą wpisy zarówno w kronice parafii, jak i rejestrze „Słowo Boże w kościele parafialnym św. Rodziny w Tarnowie"55. Nadto pisano sprawozdania z odbytych rekolekcji dla wychodźców, które publikowane były m.in. w „Currendzie. Piśmie urzędowym diecezji tarnowskiej”, „Rocznikach Obydwóch Zgromadzeń św. Wincentego a Paulo" ${ }^{56}$. Na życzenie bpa Wałęgi urządzano w grudniu każdego roku

przywié́li. Nie zawsze to jednak wystarcza zwłaszcza dla takich, którym spowszedniały spowiedzi i kazania, w których duszy nagromadziło się wiele niezdrowego osadu. Tacy potrzebują gębszego wniknięcia w siebie i gruntownego przeglądu duszy, aby się naprawdę odnowili; mogą to tylko znaleźć $\mathrm{w}$ formalnych rekolekcyach, odprawionych w zupełnem odcięciu od świata. Zeszłoroczna próba urządzona przez X.X. Misyonarzy w Tarnowie, wypadła nadspodziewanie pomyślnie. Tą udałą próbą zachęcony uprosiłem i w tym roku X. Superyora, aby także w ciągu tej zimy urządził rekolekcye dla naszych wychodźców. Rzeczą będzie X.X. Proboszczów dostarczyć uczestników tych ćwiczeń duchownych przez stosowną zachętę i pośrednictwo w zgłaszaniu. Dla większej wygody uczestników w tym roku urządzą X.X. Misyonarze 4 serye rekolekcyi i to w następującym porządku: 1 . W poniedziałek po drugiej niedzieli adwentu, czyli dnia 11 grudnia b.r. wieczorem rozpoczną się rekolekcye dla dziewcząt, a zakończą się dnia 15 grudnia rano wspólną Komunią św.; 2. Po trzeciej niedzieli adwentowej w poniedziałek t. j. dnia 18. grudnia wieczorem rozpoczną się nauki dla chłopców i mężczyzn, a zakończą się po trzech dniach czyli 21. grudnia rano; 3. Trzecia serya będzie znowu dla dziewcząt i zacznie się po świętach dnia 27. grudnia wieczorem, a zakończy się w niedzielę rano 31. grudnia; 4. Ostatnia serya dla chłopców rozpocznie się po Nowym Roku we wtorek wieczorem, czyli 2. stycznia 1912 i trwać będzie również 3 dni z zakończeniem 6. stycznia rano w uroczystość Trzech Króli. Z końcem każdej seryi będę udzielał Sakramentu Bierzmowania w kościele X.X. Misyonarzy i to popołudniu w dzień poprzedzający Komunię św. Wobec tego odpadnie w tym roku doroczne bierzmowanie w katedrze, jakie dla wychodźców odbywać się ma w niedzielę po Nowym Roku. Ktoby pragnął przystąpić do Sakramentu Bierzmowania, może przylączyć się do jednej z powyższych seryi, choćby nawet nie odprawiał rekolekcyi razem z drugimi. X.X. Proboszczowie zechcą udzielić powyższej wiadomości swoim parafianom i zachęcić ich do wzięcia udziału w tych rekolekcyach, a to w terminie, który im się wyda dogodniejszym. Następnie zgłaszających się należy donieść do X. Superyora X.X. Misyonarzy w Tarnowie (imiennego wykazu przesyłać nie potrzeba) z dodaniem ilu uczestników i na którą seryę wybiera się do Tarnowa. Doniesienie to należy uczynić dość wcześnie, by X.X. Misyonarze mieli czas przygotować pomieszczenie i stosowne rozdzielenie uczestników. Oczywiście w rekolekcyach mogą brać udział nie tylko sami wychodźcy. Warunki uczestnictwa podobne jak w roku ubieglym. Żywię nadzieje, że P. Bóg i w tym roku zgotuje mi podobną pociechę, jakiej doznałem w roku ubiegłym na widok licznej gromady wychodźców, odprawiających gorliwie duchowe ćwiczenia. Z Ordynaryatu Biskupiego w Tarnowie, dnia 18. listopada 1911. Leon, bp". Zob. Rekolekcye dla wychodźców, Currenda, 61 (1911), nr 10, s. 97-98.

55 Zob. Archiwum Prowincji Polskiej Zgromadzenia Misji w Krakowie [AMS], Tarnów I.3. Dokumenty parafii, Słowo Boże w kościele parafialnym św. Rodziny w Tarnowie, rps, b. sygn., b. pag.

56 Ks. Ignacy Dudziak zanotował w 1913 r., że: „Rekolekcje te są bardzo potrzebne, bo niejeden przebywając cały rok na obczyźnie, zapomniał o Bogu, o przykazaniach. Tu poznaje swoje 
cztery serie rekolekcji dla migrantów. W spowiedziach pomagali księżom Misjonarzom miejscowi kapłani z innych zgromadzeń w Tarnowie (filipini, bernardyni) i parafii (księża diecezjalni). Na koniec każdej serii przybywał bp Wałęga, który zachęcał rekolektantów do wytrwania w dobrym i udzielał im sakramentu bierzmowania ${ }^{57}$.

W 1911 r. księża Misjonarze w Tarnowie urządzili cztery serie rekolekcji dla wychodźców sezonowych: dwie dla młodzieńców i dwie dla dziewcząat ${ }^{58}$, w 1912 r. trzy serie $^{59}$, a w 1913 r. cztery serie ${ }^{60}$. Łącznie przeprowadzono dziewięć serii rekolekcji. Terminarze rekolekcji były uprzednio publikowane, ze stosownym wyprzedzeniem, $\mathrm{w}$ „Currendzie” oraz zapowiadane z ambony w poszczególnych parafiach diecezji tarnowskiej.

Szczegółowy wykaz wszystkich serii rekolekcji dla wychodźców w kościele księży Misjonarzy w Tarnowie i tematykę głoszonych przez nich nauk przedstawia poniższa tabela ${ }^{61}$.

Tabela 1. Rekolekcje dla wychodźców w kościele księży Misjonarzy w Tarnowie w latach 19101912

\begin{tabular}{|c|c|c|c|}
\hline Data & Nauka & Misjonarz (CM) prowadzący nauki & Tematyka nauk \\
\hline \multicolumn{4}{|c|}{ Rekolekcje dla dziewcząt - seria I. } \\
\hline 12 XII $1910 \mathrm{r}$. & Wstęp na & Ks. J. Słupina & O zbawieniu duszy \\
\hline \multirow{4}{*}{13 XII $1910 \mathrm{r}}$. & 1. & Ks. S. Leśniowski & O grzechu \\
\hline & 2. & Ks. S. Tyczkowski & O rachunku sumienia \\
\hline & 3. & Ks. J. Słupina & O żalu \\
\hline & 4. & Ks. F. Bibrzycki & O śmierci \\
\hline
\end{tabular}

przewinienia, nawraca się, nabiera nowych sił i postanawia Panu Bogu wiernie służyć”, Roczniki Obydwóch Zgromadzeń św. Wincentego a Paulo 9 (1913), z. 2, s. 164-173.

57 Zob. Sprawozdanie z rekolekcyi dla wychodźców u XX. Misyonarzy w Tarnowie, Currenda 61 (1911), nr 3, s. 25.

58 Zob. Rekolekcye dla wychodźców, tamże, 61 (1911), nr 10, s. 97-98.

59 Zob. Rekolekcye dla wychodźców sezonowych, tamże, 62 (1912), nr 11, s. 135-136. Rok 1912 był nieco gorszy, gdyż „rekolekcje te wypadły dosyć słabo wskutek spóźnionych prac rolnych większa część wcale do Galicji nie wróciła”. Por. Tarnów. List.

60 Zob. Rekolekcye dla wychodźców sezonowych, Currenda 63 (1913), nr 14, s. 99.

61 Problematykę tę szczegółowo zbadał ks. Stanisław Piech, jednak zapisał: „Nasuwa się pytanie, jaka była tematyka poszczególnych konferencji rekolekcyjnych? Niestety, nie zachowały się ani szkice głoszonych konferencji, ani wykazy ich tematów”. Zob. S. Piech, Biskup Leon Watęga, organizator duszpasterstwa emigrantów w diecezji tarnowskiej (1901-1933), Studia Polonijne 8 (1984), s. 177. Oryginalne dokumenty w tej sprawie jednak zachowaty się w Archiwum Prowincji Polskiej Zgromadzenia Misji w Krakowie na Stradomiu w zespole Tarnów, a nie w innych zespołach, które przebadał ks. S. Piech. 


\begin{tabular}{|c|c|c|c|}
\hline \multirow{3}{*}{14 XII $1910 \mathrm{r}}$. & 1. & Ks. J. Słupina & O spowiedzi \\
\hline & 2. & Ks. F. Bibrzycki & O grzechu przeciw VIII przykazaniu \\
\hline & 3. & Ks. S. Leśniowski & O sądzie \\
\hline \multirow{4}{*}{15 XII $1910 \mathrm{r}$. } & 1. & Ks. J. Stupina & O zadośćuczynieniu \\
\hline & 2. & Ks. S. Tyczkowski & O bierzmowaniu \\
\hline & 3. & Ks. F. Bibrzycki & O Komunii św. \\
\hline & 4. & Ks. bp L. Wałęga & b.d. \\
\hline \multicolumn{4}{|c|}{ Rekolekcje dla młodzieńców - seria II. } \\
\hline 19 XII $1910 \mathrm{r}$. & Wstępna & Ks. S. Leśniowski & O zbawieniu \\
\hline \multirow{4}{*}{20 XII $1910 \mathrm{r}$. } & 1. & Ks. F. Bibrzycki & O grzechu \\
\hline & 2. & Ks. S. Leśniowski & O rachunku sumienia \\
\hline & 3. & Ks. S. Tyczkowski & O żalu \\
\hline & 4. & Ks. J. Stupina & O spowiedzi \\
\hline \multirow{3}{*}{21 XII $1910 \mathrm{r}}$. & 1. & Ks. F. Bibrzycki & O grzechu \\
\hline & 2. & Ks. S. Leśniowski & O pijaństwie \\
\hline & 3. & Ks. J. Słupina & O zadośćuczynieniu \\
\hline \multirow{4}{*}{22 XII $1910 \mathrm{r}$. } & 1. & Ks. F. Bibrzycki & O przekleństwie \\
\hline & 2. & Ks. J. Słupina & O nieczystości \\
\hline & 3. & Ks. S. Leśniowski & O Komunii św. \\
\hline & 4. & Ks. F. Bibrzycki & O bierzmowaniu \\
\hline 23 XII $1910 \mathrm{r}$. & 1. & Ks. bp L. Wałęga & O wytrwaniu \\
\hline \multicolumn{4}{|c|}{ Rekolekcje dla dziewcząt - seria II. } \\
\hline 2 I $1911 \mathrm{r}$. & Wstępna & Ks. W. Mierzejewski & O zbawieniu \\
\hline \multirow{4}{*}{$3 \mathrm{I} 1911 \mathrm{r}}$. & 1. & Ks. J. Słupina & O grzechu \\
\hline & 2. & Ks. S. Włodarczyk & O rachunku sumienia \\
\hline & 3. & Ks. F. Bibrzycki & O żalu \\
\hline & 4. & Ks. S. Leśniowski & O spowiedzi \\
\hline \multirow{3}{*}{$4 \mathrm{I} 1911 \mathrm{r}}$. & 1. & Ks. S. Leśniowski & O zadośćuczynieniu \\
\hline & 2. & Ks. F. Bibrzycki & O grzechach przeciwnych VIII przykazaniu \\
\hline & 3. & Ks. F. Bibrzycki & O sądzie \\
\hline \multirow{4}{*}{$5 \mathrm{I} 1911 \mathrm{r}$. } & 1. & Ks. S. Włodarczyk & O czystości \\
\hline & 2. & Ks. S. Leśniowski & O bierzmowaniu \\
\hline & 3. & Ks bp L. Wałęga & O ważności rekolekcji \\
\hline & 4. & Ks. J. Słupina & O Komunii świętokradzkiej \\
\hline \multicolumn{4}{|c|}{ Rekolekcje dla dziewcząt - seria III. } \\
\hline 27 XII $1911 \mathrm{r}$. & Wstępna & Ks. H. Gintrowski & O zbawieniu \\
\hline \multirow{3}{*}{28 XII $1911 \mathrm{r}$. } & 1. & Ks. I. Dudziak & O grzechu śmiertelnym \\
\hline & 2. & Ks. H. Gintrowski & O pokucie i żalu \\
\hline & 3. & Ks. S. Leśniowski & O rzeczach ostatecznych \\
\hline \multirow{3}{*}{29 XII $1911 \mathrm{r}}$. & 1. & Ks. S. Leśniowski & O spowiedzi \\
\hline & 2. & b.d. & O zadośćuczynieniu \\
\hline & 3. & Ks. I. Dudziak & O Komunii św. \\
\hline
\end{tabular}




\begin{tabular}{|c|c|c|c|}
\hline \multirow{3}{*}{30 XII $1911 \mathrm{r}$. } & 1. & Ks. S. Leśniowski & O bierzmowaniu \\
\hline & 2. & Ks. I. Dudziak & O miłości bliźniego \\
\hline & 3. & Ks. S. Tyczkowski & O wytrwałości \\
\hline \multicolumn{4}{|c|}{ Rekolekcje dla młodzieńców i chłopców - seria IV. } \\
\hline 2 I 1912 r. & Wstępna & Ks. H. Gintrowski & O zbawieniu \\
\hline \multirow{3}{*}{3 I $1912 \mathrm{r}}$. & 1. & Ks. S. Leśniowski & O grzechu i skutkach \\
\hline & 2. & Ks. H. Gintrowski & O pokucie i żalu \\
\hline & 3. & Ks. I. Dudziak & O rzeczach ostatecznych \\
\hline \multirow{4}{*}{4 I 1912 r. } & 1. & Ks. H. Gintrowski & O spowiedzi \\
\hline & 2. & Ks. S. Leśniowski & O zadośćuczynieniu \\
\hline & 3. & Ks. I. Dudziak & O Komunii św. \\
\hline & 4. & Bp L. Wałęga & O wytrwałości i sakramencie bierzmowania \\
\hline \multicolumn{4}{|c|}{ Rekolekcje dla dziewcząt - seria I. } \\
\hline 2 XII $1912 \mathrm{r}$. & Wstępna & Ks. I. Dudziak & Cel człowieka i jak przepędzić rekolekcje \\
\hline \multirow{3}{*}{3 XII 1912 r. } & 1. & Ks. S. Leśniowski & O grzechu śmiertelnym \\
\hline & 2. & Ks. L. Pawliński & O pokucie i żalu \\
\hline & 3. & Ks. S. Piasecki & O śmierci \\
\hline \multirow{3}{*}{4 XII 1912 r. } & 1. & Ks. S. Leśniowski & Spowiedź i zadośćuczynienie \\
\hline & 2. & Ks. I. Dudziak & Nauka stanu \\
\hline & 3. & Ks. L. Pawliński & Skutki Komunii św. \\
\hline \multicolumn{4}{|c|}{ Rekolekcje dla dziewcząt - seria II. } \\
\hline 9 XII $1912 \mathrm{r}$. & Wstępna & Ks. I. Dudziak & Cel człowieka i jak przepędzić rekolekcje \\
\hline \multirow{3}{*}{10 XII 1912 r. } & 1. & Ks. S. Leśniowski & O grzechu śmiertelnym \\
\hline & 2. & Ks. L. Pawliński & O żalu i postanowieniu poprawy \\
\hline & 3. & Ks. S. Piasecki & O śmierci \\
\hline \multirow{3}{*}{11 XII 1912 r. } & 1. & Ks. S. Leśniowski & O spowiedzi \\
\hline & 2. & Ks. I. Dudziak & O miłości bliźniego \\
\hline & 3. & Ks. S. Leśniowski & O zadośćuczynieniu \\
\hline \multirow{2}{*}{12 XII 1912 r. } & 1. & Ks. S. Tyczkowski & Nauka stanu \\
\hline & 2. & Ks. L. Pawliński & O komunii św. \\
\hline \multicolumn{4}{|c|}{ Rekolekcje dla młodzieńców i chłopców - seria I. } \\
\hline 16 XII $1912 \mathrm{r}$. & Wstępna & Ks. I. Dudziak & Cel człowieka i jak przepędzić rekolekcje \\
\hline \multirow{3}{*}{17 XII 1912 r. } & 1. & Ks. S. Leśniowski & O grzechu śmiertelnym \\
\hline & 2. & Ks. L. Pawliński & O skrusze i postanowieniu poprawy \\
\hline & 3. & Ks. S. Piasecki & Sąd ostateczny \\
\hline \multirow{3}{*}{18 XII 1912 r. } & 1. & Ks. S. Leśniowski & Spowiedź i rachunek sumienia \\
\hline & 2. & Ks. S. Piasecki & O zadośćuczynieniu \\
\hline & 3. & Ks. L. Pawliński & O komunii św. \\
\hline 19 XII 1912 r. & Zakończenie & Ks. S. Piasecki & O wytrwaniu \\
\hline
\end{tabular}

Źródło: Opracowano na podstawie AMS, Tarnów I.3. Dokumenty parafii l, „Słowo Boże” w kościele parafialnym św. Rodziny w Tarnowie od 31 X 1908 r. do 20 X 1918 r. Kazania naszych księży w obcych kościołach, b. pag. 
Z powyższego zestawienia wynika, że rekolekcje dla wychodźców sezonowych odbywały się seriami na przełomie danego roku z podziałem na płeć, gdy migranci przybywali gremialnie do rodzinnych domów na święta Bożego Narodzenia i Nowy Rok. Rozpoczynała je nauka wstępna, a następnie przez trzy kolejne dni rekolektanci wysłuchiwali po trzy nauki dziennie. Na zakończenie naukę głosił bp L. Wałęga i udzielał młodym wychodźcom sakramentu bierzmowania. Nie praktykowano prowadzenia rekolekcji wiosną ( $w$ Wielkim Poście) ze względu na znacznie niższy odsetek przybywających w rodzinne strony migrantów. Większość z nich zatrudniona była za granicą przy pracach polowych, które wczesną wiosną już trwały także na obczyźnie. Trudno dociec z braku szczegółowych harmonogramów, sprawozdań, jaka była tematyka rekolekcji parafialnych dla pozostałych w misjonarskiej i innych parafiach diecezji tarnowskiej. Z pewnością niektóre tematy nauk zazębiały się z problematyką poruszaną dla wychodźców. Trzeba jednakże pamiętać, że uchodźcy wywodzili się $\mathrm{z}$ wielu parafii rozsianych w całej diecezji tarnowskiej. W każdej z nich były prowadzone przed świętami Bożego Narodzenia i Wielkanocnymi rekolekcje, a przed wizytacjami kanonicznymi misje parafialne. Temat ten wydaje się interesujący i godny odrębnych pogłębionych badań porównawczych, zarówno w zakresie historycznosocjologicznym, jak i teologicznym.

Czas pokazał, że rekolekcje te były skuteczną pomocą dla młodych migrantów. Biskup Wałęga wychodził ze słusznego założenia, że „jeżeli lud będzie dobrze przygotowany na emigrację, należycie na niej strzeżony i kierowany, to nie zrobi krajowi wstydu, ale zyska materialnie, nie tracąc też duchowo" ${ }^{2}$. Należy wspomnieć, że konsystorz biskupi w Tarnowie prowadził monitoring migracji $\mathrm{w}$ formie ankietowej, a problemy migracyjne omawiane były na zebraniach dekanalnych ${ }^{63}$. W $1907 \mathrm{r}$. opracowana została szczegółowa ankieta odnośnie do wychodźstwa. Druga wersja ankiety została opracowana w $1910 \mathrm{r}$. Zostały one opublikowane przez konsystorz biskupi w „Currendzie” ${ }^{64}$. Poszczególni proboszczowie zobowiązani byli przesyłać wypełnione ankiety do konsystorza. Były one następnie analizowane i opracowywane. Podobne ankiety zastosowano w innych diecezjach, w tym Królestwa Polskiego. Przykładowo, ankietę w 1907 r. wprowadzono w diecezji płockiej. Tamże, jak zaznacza J. Kulikowska „ankiety diecezjalne wypełniane przez proboszczów, dawały właściwy obraz fali emigracyjnej. Proboszczowie bowiem byli najlepiej poinformowani

\footnotetext{
62 Zob. J. Adamczyk, Działalność duszpasterska, s. 87.

63 Szerzej: S. Piech, Emigracje z diecezji tarnowskiej, s. 145-197.

64

Zob. Ankieta Konsystorza.
} 
o swoich parafianach-emigrantach udających się za chlebem, i to niezależnie jaką drogą, legalną czy w sposób nielegalny ${ }^{65}$. Trzeba podkreślić, że na ogół proboszczowie nawiązywali i podtrzymywali kontakt słowny, listowy z wychodźcami ze swojej parafii. Na drogę wręczali im poświęcone dewocjonalia, broszury, pisma katolickie i list bpa Wałęgi „Archanioł Rafał, czyli list pasterski o wychodźstwie” z 1906 r. Nie szczędzili słów napomnień, modlili się za nich. Również czynili tak i księża Misjonarze, dla których dobro migrantów było jednym z priorytetów ówczesnej ich pracy w Tarnowie.

Migracja zarobkowa z Galicji wyhamowała podczas pierwszej wojny światowej, natomiast spowodowała falę migracji przymusowych, uchodźczych, niezarobkowych ${ }^{66}$. W 1914 r. Galicję opuściło ok. 800 tys. osób, chroniąc się przed inwazją rosyjską w Austrii, na Węgrzech, w Czechach i na Śląsku Cieszyńskim. Byli wśród nich również tarnowianie ${ }^{67}$. Duże nierzadko perturbacje były z powrotem podczas pierwszej wojny światowej młodocianych robotników sezonowych do swoich polskich domów ${ }^{68}$. W sprawie wychodźstwa sezonowego rozpisywała się ówczesna prasa. Należy zaznaczyć, że zagadnienia duszpasterstwa emigrantów nie zakończyły się wraz z pierwszą wojną światową.

W Europie najkorzystniejsze warunki pracy i płacy mieli nasi rodacy w Danii. Kraj ten wspomagał Polaków ${ }^{69}$. Trzeba jednak zaznaczyć, że niepokojącym zjawiskiem podczas (ale nie tylko) pierwszej wojny światowej były małżeństwa Polek z Duńczykami wyznania luterańskiego ${ }^{70}$. Różnice dotyczące wiary, samej koncepcji małżeństwa, a także odmiennych mentalności religijnych nierzadko były przyczyną napięć w małżeństwie, zwłaszcza w odniesieniu do wychowania dzieci. Zaobserwowano występowanie zobojętnienia religijnego, jak i zupełne odejście od wiary. Nadto obserwowano rozpady małżeństw mieszanych z racji różnic w podejściu i praktyko-

65 Por. J. Kulikowska, Emigracja i duszpasterstwo, s. 95.

66 Szerzej wątek ten podjął w swojej publikacji Kamil Ruszała (Galicyjski Eksodus. Uchodźcy $z$ Galicji podczas I wojny światowej w monarchii Habsburgów, Kraków 2020).

67 Zob. Księga pamiątkowa i adresowa wygnańców wojennych z Galicyi i Bukowiny 1914-1915 oraz Album pamiątkowe, część III. Prowincya i Bukowina, Wiedeń 1915.

68 Zob. O powrót $z$ Niemiec młodocianych robotników sezonowych, Currenda 68 (1918), nr 5, s. 42-43.

69 Pisano o tym w wielu ówczesnych czasopismach, dziennikach - np. Danja dla Polski, Kurjer Polski, 6 I 1917, nr 6, s. 1.

70 Duńczycy to wyznawcy protestantyzmu ewangelicko-luterańskiego. Szerzej: T.J. Zieliński, Protestantyzm ewangelikalny. Studium specyfiki religijnej, Warszawa 2013. 
waniu własnej wiary ${ }^{71}$. Różnorakie problemy związane z zagadnieniami moralnymi wśród wychodźców dostrzegali również biskupi diecezjalni na obczyźnie. Przykładem może być bp Johannes von Euch $^{72}$, który

gorliwie się zajął naszymi rodakami i dzięki ofiarności publicznej obsadził księży mówiących po polsku w Roskilde, Maribo, Odensie i Slagelse. Księża ci, chociaż narodowością nam obcy, nauczyli się języka polskiego i chętnie służą naszym rodakom. Do Maribo, gdzie kościół zbudował ks. Ortwed, zaprosił ks. biskup von Euch Franciszkanów z Krakowa, ci jednak placówkę tę opuścili i oddali ją Franciszkanom francuskim ${ }^{73}$.

Niekorzystne były stosunki moralne wśród wychodźców w Niemczech. Problemem na tych terenach był niedobór kapłanów. Przykładowo, na jednego księdza w Delitsch przypadali wychodźcy z dwóch miast i aż 122 wsi ${ }^{74}$. Problem wychodźstwa (emigracja zarobkowa) do obcych krajów w latach dwudziestych XX w. znalazł szerokie odbicie w postawie Episkopatu Polski. Na jego konferencji 28 III $1921 \mathrm{r}$. postanowiono zorganizować stałe duszpasterstwo dla polskich wychodźców we Francji. Konferencja Episkopatu Polski powierzyła kard. Edmundowi Dalborowi (1869-1926) zorganizowanie struktur duszpasterstwa polonijnego ${ }^{75}$. Kierownictwo Misji Polskiej na całą Francję powierzył od 13 V 1922 r. Misjonarzowi, ks. Wilhelmowi Szymborowi CM (1879-1949) ${ }^{76}$. W 1923 r. pracowało już 34 polskich kapłanów (w tym 17 będących na studiach specjalistycznych), z tego aż ośmiu w samym

71 Kościół katolicki zawsze był sceptycznie nastawiony wobec zawierania przez chrześcijan związków z niechrześcijanami, chociaż nie od razu takie związki potępiał. W Danii katolicy-obcokrajowcy nie mieli swobody kultu religijnego wyznawanej przez siebie wiary. T.J. Zieliński, Ewangelikalizm, [w: ] Religia. Encyklopedia, t. 3, red. T. Gadacz, B. Milerski, Warszawa 2011, s. 498-501.

72 Johannes Theodor Joseph von Euch (ur. 21 stycznia 1834 w Meppen, zm. 18 marca 1922 r. w Kopenhadze) - niemiecki duchowny katolicki, prefekt apostolski Danii w latach 1884-1892 i wikariusz apostolski Danii od 1892 r. W t.r. Leon XIII nominował go biskupem tytularnym Anastasiopolis. Zob. H. Holzapfel, Euch, Johannes Theodor Joseph von, [w: ] Neue Deutsche Biographie, t. 4, Berlin 1959, s. 669.

73 O wychodźctwie polskiem w Danii, Postęp, 10 V 1913, nr 106, s. 1.

74 Zob. J. Puchałka, W sprawie wychodźstwa sezonowego, Lud katolicki 4 (1917), nr 3, s. 3-4.

75 B. Kołodziej, Troska Prymasów Polski o naszych emigrantów oraz ich uprawnienia, Studia Prymasowskie 5 (2011), s. 43-55.

76 Zob. G. Garçon, Les catholiques polonais en France. Les années de fondation 1919-1949, Lille 2004. 
Paryżu ${ }^{77}$. Należy przy tym podkreślić wkład w opiekę i nadzór nad duszpasterstwem polonijnym Episkopatu Polski ${ }^{78}$. Nie można pominąć faktu, że wiele troski w zagadnienia spraw duchowych emigrantów przejawiali kolejni prymasi Polski: Aleksander Kakowski (1862-1938) ${ }^{79}$, August Hlond (1881-1948) $)^{80}$, a także bp Józef Gawlina (1892-1964) ${ }^{81}$ nazywany biskupem-tułaczem i inni hierarchowie. Nie wszędzie jednak w świecie polscy kapłani byli jako duszpasterze swoich rodaków mile widziani ${ }^{82}$. Każdy biskup danej diecezji dostrzegał problematykę uchodźstwa. Przykładowo, bp częstochowski Teodor Kubina opublikował list pasterski do wychodźców swej diecezji. Pisał w nim: „Wychodźcy winni się strzec pijaństwa; mają zagranicą kupować tylko to, co im koniecznie jest potrzebne, by cały zarobiony grosz przywieźć do ojczyzny; mają dbać o swe rodziny i z niemi żywy utrzymywać kontakt. Przede wszystkiem jednak powinni dbać o honor Polski za granicą" ${ }^{33}$. Listy innych biskupów były podobnej treści. Dominowały w nich pouczenia i przestrogi.

Warto podkreślić, że na pierwszym synodzie tarnowskim w 1928 r., dysponując wiedzą i doświadczeniem, omawiano wychodźstwo jako wydarzenie i problem duszpasterski. Początkowo synod przestrzegał przed uchodźstwem i nie udzielił mu poparcia. Wobec jednak faktu szerokiej emigracji zarobkowej, synod zarysował system duszpasterskiej opieki nad wychodźcami. System ten obejmował: zapewnienie emigrującym uświadomienia religijnego, przyjęcia sakramentów św., zaopatrzenie ich w dewocjonalia na drogę (książeczki do modlitwy, różańce), sporządzanie

77 Opieka duchowna nad robotnikami polskimi we Francji, Lud katolicki, 15 VII 1923, nr 27, s. 4-5.

78 Powołano Diecezjalną Radę Opiekuńczą dla Emigrantów. Jej prezesem został ks. infułat Józef Bąba, a zastępcą ks. dr Tomasz Włoch. Miała się ona troszczyć o sprawy duchowe emigrantów. Zob. O opiece nad emigrantami, s. 36.

79 Zob. M. Makowski, Kardynat Aleksander Kakowski metropolita warszawski (1913-1938). Kalendarium (z wypisami), Warszawa 2015.

80 Od czasu zostania prymasem Polski kard. Hlond był niezwykle wyczulony na zagadnienia opieki duszpasterskiej nad polskimi wychodźcami, pozbawionymi opieki państwowej i duszpasterskiej. Por. B. Kołodziej, Kardynał August Hlond dla Polaków za granicą, Nauczyciel i Szkoła 2 (2019), nr 70, s. 69-89.

81 D. Bednarski, Biskup Józef Gawlina jako opiekun Polaków na emigracji, Katowice 2019.

82 Pisał w tej sprawie bp Wałęga do abp. J. Bilczewskiego w liście z 21 IV 1907 r.: „Użaliłem się Ojcu św., że biskupi niemieccy nie chcą dawać jurysdykcji moim księżom, którzy odwiedzają wychodźców”. List 35, J. Wołczański, J. Wałęga do J. Bilczewskiego - listy, Nasza Przeszłość 90 (1998), s. 250.

83 Biskup Częstochowski do swoich wychodźców, Gazeta Polska, 20 III 1928, nr 66, s. 2. 
w parafiach spisów wychodźców, utrzymywanie z nimi korespondencji, serdeczna opieka po powrocie, by uwolnić ich od złych wpływów religijnych. Analogiczną pieczę duszpasterską zalecał tenże synod w $1928 \mathrm{r}$. w odniesieniu do podejmujących służbę wojskową w kraju ${ }^{84}$. W 1929 r. na emigrację udało się z Polski ponad 250 tys. obywateli, z czego aż $75 \%$ pochodziło ze wsi ${ }^{85}$. W późniejszym okresie również rząd Polski zaopiekował się emigracją. Wszedł m.in. w porozumienie z rządem francuskim, powołując wspólne organizacje, w tym Polsko-Francuską Komisję doradczą dla spraw emigracyjnych $\mathrm{w}$ Warszawie ${ }^{86}$. Ukazało się rozporządzenie francuskiego rządu, zabraniające zatrudniania emigrantów, którzy przyjechali do Francji po 1 lipca 1930 r. Bardzo boleśnie odczuło to rozporządzenie wielu przybyszów z Polski, którzy w tym czasie wyjechali do Francji w poszukiwaniu zarobku i znaleźli się bez pracy $^{87}$. Problemy migrantów były przedmiotem zainteresowania Episkopatu Polski, o czym świadczy wydana w 1932 r. odezwa prymasa Polski ${ }^{88}$.

Po drugiej wojnie światowej emigracja z kraju była utrudniona, toteż trzeci Synod diecezji tarnowskiej z 1948 r. zasady opieki duszpasterskiej odnoszące się do wychodźców zastosował tylko do współmałżonków oraz innych osób opuszczających rodzinną parafię na dłuższy czas ${ }^{89}$. Migracja zarobkowa Polaków, tarnowian, parafian, nie zakończyła się po drugiej wojnie światowej, ale trwała ${ }^{90} \mathrm{i}$ jest kontynuowana nadal w obecnej rzeczywistości. Stąd również i troska Kościoła katolickiego była ze wszech miar zarówno pożądana, jak i uzasadniona ${ }^{91}$. Opieka duszpasterska dla Polonii na obczyźnie trwa nieprzerwanie nadal. 2 maja obchodzony jest Dzień Polonii i Polaków za Granicą.

Podjęta próba zaprezentowania zagadnienia na styku emigracji i rekolekcji dla migrantów nie pretenduje do pełnej analizy ani do wyczerpania tej tematyki. Wy-

\footnotetext{
84 Por. Pierwszy synod diecezji tarnowskiej, Tarnów 1928, s. 79-80.

85 W pogoni za praca. Tydzień emigranta, Głos Pracy, 1 III 1930, nr 7, s. 4.

86 Łuk., Emigracja robotników polskich do Francji, tamże, 1 II 1930, nr 3, s. 3-4.

87 Por. Wychodźtwo[!] do Francji zamknięte, Nowa Zorza, 1 III 1931, nr 1, s. 17.

88 Zob. Odezwa J.E. Augusta kardynała Hlonda, Prymasa Polski do społeczeństwa Polskiego w sprawie „Opieki nad rodakami na obczyźnie”, Currenda 82 (1932), nr 10, s. 97.

89 Por. statuty 87-88, [w: ] Trzeci synod, s. 366-376.

90 W latach siedemdziesiątych i osiemdziesiątych XX w. parafianie Świętej Rodziny w Tarnowie migrowali w celach zarobkowych najczęściej do USA. Natomiast z końcem XX w. i początkiem XXI w. do krajów Europy Zachodniej.

91 Zob. Katolicka opieka nad emigracja, Ruch Katolicki. Organ Akcji Katolickiej w Polsce 6 (1939), s. 299-300.
} 
maga ona dalszych badań. Artykuł stanowi przyczynek i zachęca do szerszego spojrzenia na te niedogłębnie przebadane kwestie.

The migration issues of the $20^{\text {th }}$ century and the care of the Catholic Church for seasonal emigrants on the example of the Tarnów diocese in 1910-1913.

\section{Bibliografia}

\section{Źródła archiwalne}

Acta Apostolicae Sedis 1929, t. 21, nr 16.

Adamczyk J., Działalność duszpasterska na rzecz wychodźców galicyjskich w diecezji tarnowskiej, Tarnów 1978, mps, sygn. 01341 MGR.

AKMT, Kronika parafii, t. 1.

Archiwum Instytutu Teologicznego w Tarnowie

Archiwum Parafii pw. Świętej Rodziny w Tarnowie

Archiwum Prowincji Polskiej Zgromadzenia Misji w Krakowie

Tarnów I.3. Dokumenty parafii, Stowo Boże w kościele parafialnym św. Rodziny w Tarnowie, rps.

\section{Opracowania}

Ankieta Konsystorza biskupiego w Tarnowie z 1907 r.w sprawie wychodźstwa, Currenda. Pismo urzędowe diecezji tarnowskiej 54 (1904), nr 2, s. 13-15.

Badeni J., Robotnicy polscy w Saksonii, Przegląd Powszechny. Miesięcznik poświęcony sprawom religijnym, kulturalnym i społecznym 7 (1890), t. 28, s. 322.

Bednarski D., Biskup Józef Gawlina jako opiekun Polaków na emigracji, Katowice 2019.

Borys M., Z dziejów galicyjskiego wychodźstwa zarobkowego do Stanów Zjednoczonych, Szkice Tarnowskie 1 (2010), nr 1, s. 89-102.

Dworaczyk E.J., The First Polish Colonies of America in Texas, San Antonio, Texas 1936.

Dyktus J., Emigracja i opieka duszpasterska nad emigrantami w diecezji krakowskiej $w$ świetle ankiet konsystorza z 1907 i 1913 roku, Studia Polonijne 2 (1977), s. $113-180$.

Emigracja z ziem polskich $w$ czasach nowożytnych i najnowszych $w$ XVIII-XX w., red. A. Pilch, Warszawa 1984. 
Garçon G., Les catholiques polonais en France. Les années de fondation 1919-1949, Lille 2004.

Holzapfel H., Euch, Johannes Theodor Joseph von, [w: Neue Deutsche Biographie, t. 4, Berlin 1959, s. 669.

Kołodziej B., Kardynat August Hlond dla Polaków za granica, Nauczyciel i Szkoła 2 (2019), nr 70, s. 69-89.

Kołodziej B., Opieka duszpasterska nad wychodźcami polskimi do roku 1939, Poznań 2003.

Kołodziej B., Troska Prymasów Polski o naszych emigrantów oraz ich uprawnienia, Studia Prymasowskie 5 (2011), s. 43-55.

Koseski A., Procesy migracji i społeczności polonijne. Problematyka metodologiczno-historiograficzna, Pułtusk 2003.

Kosmowska I.W., Nasze wychodźstwo do Francji, Ziemia. Dwutygodnik krajoznawczy ilustrowany 13 (1928), nr 13, s. 202-205.

Kościesza A., Robotnik rolny a wychodźtwo[!], Warszawa 1913.

Kowalski G.M., Przestępstwa emigracyjne w Galicji 1897-1918. Z badań nad dziejami polskiego wychodźstwa, Kraków 2003.

Kozaczka M., Emigracja zarobkowa z powiatu tarnowskiego do $r$. 1939, Przegląd Polonijny 3 (1990), z. 16, s. 59-76.

Kruszka W., Historya Polska w Ameryce, t. 1, Milwaukee 1905.

Księga pamiątkowa i adresowa wygnańców wojennych $z$ Galicyi i Bukowiny 1914-1915 oraz Album pamiątkowe, część III. Prowincya i Bukowina, Wiedeń 1915.

Kulikowska J, Emigracja i duszpasterstwo wychodźców z Królestwa Polskiego do roku 1914 ( w świetle urzędowych publikacji kościelnych), Nasza Przeszłość 65 (1986), s. 91-143.

Kurtyka P., CM, Z pracy duszpasterskiej wśród robotników polskich we Francji, Roczniki Obydwóch Zgromadzeń św. Wincentego a Paulo 25 (1923), nr 1, s. 22.

List biskupa tarnowskiego J.A. Pukalskiego [z 24 III 1880 r.], Currenda. Pismo urzędowe diecezji tarnowskiej 30 (1880), nr 9, s. 65-67.

Makowski M., Kardynat Aleksander Kakowski metropolita warszawski (1913-1938). Kalendarium (z wypisami), Warszawa 2015.

Mazurek J., Kraj a emigracja. Ruch ludowy wobec wychodźstwa chłopskiego do krajów Ameryki Łacińskiej (do 1939 roku), Warszawa 2006.

Mechanizmy zamorskich migracji łańcuchowych w XIX wieku: Polacy, Niemcy, Żydzi, Rusini. Zarys problemu, red. D. Praszałowicz, K. Makowski, A.A. Zięba, Kraków 2004. 
Odezwa J.E. Augusta kardynała Hlonda, Prymasa Polski do społeczeństwa Polskiego w sprawie „Opieki nad rodakami na obczyźnie”, Currenda. Pismo urzędowe diecezji tarnowskiej 82 (1932), nr 10, s. 97.

O opiece nad emigrantami (referat X. pratata dr Jana Bernackiego), Currenda. Pismo urzędowe diecezji tarnowskiej 62 (1912), nr 2, s. 35-36.

O powrót $z$ Niemiec młodocianych robotników sezonowych, Currenda. Pismo urzędowe diecezji tarnowskiej 68 (1918), nr 5, s. 42-43.

Piech S., Biskup Leon Wałęga, organizator duszpasterstwa emigrantów w diecezji tarnowskiej (1901-1933), Studia Polonijne 1984, t. 8, s. 177.

Piech S., Emigracje z diecezji tarnowskiej w świetle ankiet konsystorza z lat 1907 i 1910, Nasza Przeszłość 1986, t. 65, s. 145-197.

Piech S., Opieka nad emigrantami $w$ diecezji tarnowskiej, Collectanea Theologica. Przegląd teologiczny 55 (1985), nr 3, s. 169-177.

Pierwszy synod diecezji tarnowskiej, Tarnów 1928.

Pilch A., Emigracja z ziem zaboru austriackiego (od potowy XIX w. do 1918 r.), [w: ] Emigracja zziem polskich, s. 252-325.

Pius XI, encyklika Mens nostra, Acta Apostolicae Sedis, 1929, t. 21, nr 16, s. 689-706. Polacy na obczyźnie. IV. Polacy w Danii, Goniec Śląski 8 (1928), nr 230, s. 5.

Poradnik dla wychodźcy. O czem emigrant zarobkowy we Francji wiedzieć powinien, oprac. S. Klimowicz, Paryż 1923.

Puchałka J., W sprawie wychodźstwa sezonowego, Lud katolicki 4 (1917), nr 3, s. 3-4. Pukalski J.A., Ostrzeżenie wtościan polskich by lekkomyślnie kraju rodzinnego nie opuszczali, aby w Ameryce szukać rzekomej poprawy losu swego, Currenda. Pismo urzędowe diecezji tarnowskiej 30 (1880), nr 14, s. 106-112.

Rekolekcye dla wychodźców, Currenda. Pismo urzędowe diecezji tarnowskiej 61(1911), nr 10, s. 97-98.

Rekolekcye dla wychodźców sezonowych, Currenda. Pismo urzędowe diecezji tarnowskiej62 (1912), nr 11, s. 135-136.

Rekolekcye dla wychodźców sezonowych, Currenda. Pismo urzędowe diecezji tarnowskiej 63 (1913), nr 14, s. 99.

Ruszała K. Galicyjski Eksodus. Uchodźcy z Galicji podczas I wojny światowej w monarchii Habsburgów, Kraków 2020.

Skutki wychodźstwa do Ameryki, Krakus. Pismo poświęcone sprawom politycznym i społecznym 2 (1892), nr 23, s. 8.

Sprawozdanie kasowe, Currenda. Pismo urzędowe diecezji tarnowskiej 64 (1914), nr 13, s. 67. 
Sprawozdanie z pracy misyjnej w Król. Saskiem w r. 1912, Currenda. Pismo urzędowe diecezji tarnowskiej 53 (1913), nr 4, s. 30-32.

Sprawozdanie z rekolekcyi dla wychodźców u XX. Misyonarzy w Tarnowie, Currenda.

Pismo urzędowe diecezji tarnowskiej, 61 (1911), nr 3, s. 25.

Tarnów. List ks. Ignacego Dudziaka z 12 lutego 1913 r., Roczniki Obydwóch Zgromadzeń św. Wincentego a Paulo 19 (1913), z. 4, s. 164-173.

Trzeci synod diecezji tarnowskiej 1948, Tarnów 1957.

Walaszek A., Migracje Europejczyków 1650-1914, Kraków 2007.

Walaszek A., Polscy robotnicy, praca i związki zawodowe w Stanach Zjednoczonych Ameryki, 1880-1922, Wrocław 1988.

Walaszek A., Reemigracja ze Stanów Zjednoczonych do Polski po I wojnie światowej, 1919-1924, Kraków 1983.

Walaszek A., Światy imigrantów. Tworzenie polonijnego Cleveland, Ohio 1880-1930, Kraków 1994.

Wałęga L., WW Duchowieństwu Diecezyi pozdrowienie i błogosławieństwo, Currenda. Pismo urzędowe diecezji tarnowskiej 60 (1910), nr 15, s. 153-160.

Wołczański J., J. Wałęga do J. Bilczewskiego - listy, Nasza Przeszłość, 1998, t. 90, s. 250.

Wskazówki dla wychodźców do Brazylii, Warszawa 1929.

Wskazówki dla wychodźców udających się do Ameryki oraz rozmówki polsko-angielskie, ułożył J. Okołowicz, Kraków 1911.

Zieliński T.J., Protestantyzm ewangelikalny. Studium specyfiki religijnej, Warszawa 2013.

Zieliński T.J., Ewangelikalizm, [w: ] Religia. Encyklopedia, t. 3, red. T. Gadacz, B. Milerski, Warszawa 2011, s. 498-501.

\section{Prasa}

„Gazeta Polska. Codzienne pismo polsko-katolickie” 32 (1928).

„Głos Pracy. Dwutygodnik chrześcijańsko-społeczny” 1 (1930).

„Gwiazda katolicka. Czasopismo religijno-naukowe, społeczne i beletrystyczne” 1 (1890).

„Kurjer Polski” 20 (1917).

„Lud katolicki” 4 (1917)-11 (1923).

„Nowa Zorza” 35 (1931) 3.

„Pogoń. Tygodnik polityczny i ekonomiczno-społeczny” 9 (1889)-34 (1914). 
„Postęp” 24 (1913).

„Ruch Katolicki. Organ Akcji Katolickiej w Polsce” 9 (1939).

„Społeczna Praca. Tygodnik polityczny, ekonomiczno-społeczny i informacyjny” 1 (1925).

„Tygodnik Mieszczański” 3 (1913).

„Związek Chłopski. Organ stronnictwa chłopskiego i klubu sejmowego katolicko-ludowego" 11 (1904).

\section{Summary}

Emigration in the $20^{\text {th }}$ century and the Catholic Church's care for seasonal emigrants: the example of the Tarnów diocese in 1910-1913

In the early $20^{\text {th }}$ century, as a result of temporary mass economic emigration from Galicia, Eastern Europe, spiritual retreats were organised to serve the young people. Leon Wałęga, the bishop of Tarnów, appointed the church and missionary priests in Tarnów to organize spiritual retreats held in 1910-1913 in the Holy Family missionary parish. The Catholic Church took care of the moral and spiritual condition of the emigrants, specifically young people. Since it was a closed retreat, the missionaries provided the participants with temporary accommodation and food for a nominal fee. The spiritual retreats were organised separately for men and women and took 3 to 5 days. The results of the spiritual exercises were presented in the form of questionnaires by the priests from the emigrants' home parishes. The bishop's idea, aimed at reminding young emigrants of the catechism and the articles of faith, proved right and useful. Lists of the topics of the teachings conducted by individual missionary priests have been preserved.

Nadesłany: 19 I 2021

Nadesłany po poprawkach recenzyjnych: 15 V 2021

Zaakceptowany: 31 V 2021

Dr Paweł Glugla

badacz niezależny

e-mail: pawel.glugla@interia.pl 